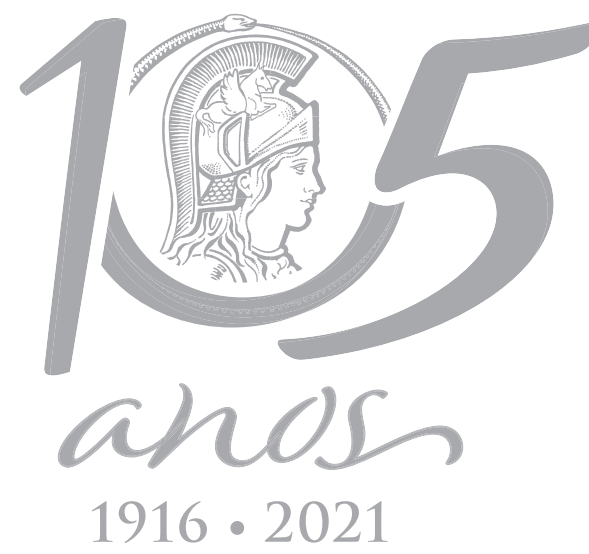

\title{
MICROBIOLOGY
}

\section{Characteristics of two terbutylazine- degrading bacteria and the construction of a live bacterial agent for effective degradation of terbutylazine in soil}

\author{
JIANGWEI ZHU, YAN ZHAO, XIAOLOU LI \& LI FU
}

\begin{abstract}
Two kinds of bacteria, named TDJ-7 and TDJ-9, were isolated from the soil, which could degrade terbutylazine effectively. TDJ-7 and TDJ-9 were identified as Bacillus pumilus and Bacillus subtilis. The degradation efficiency of $10 \mathrm{mg} / \mathrm{L}$ of terbutylazine by TDJ-7 could reach 95\% within 6 days, and the strain TDJ-9 could reach $98 \%$ under the same conditions. Both strain TDJ-7 and strain TDJ-7 could also effectively degrade simazine, metribuzin, atrazine and ametryn. In addition, strain TDJ-7 and TDJ-9 had been successfully developed into a live bacterial agent that could be used to degrade terbutylazine residue. These results suggest that strain TDJ-7 and TDJ-9 can be used for the bioremediation of terbutylazine or other s-triazine herbicides contamination.
\end{abstract}

Key words: terbutylazine, s-triazine herbicide, microbial degradation, microbial agent.

\section{INTRODUCTION}

Terbutylazine (CAS: 5915-41-3.) was widely used for weed control in crops (Brown 2018). Longterm use of terbutylazine resulted in its high residue levels in water and soil (Bottoni et al. 2013). Terbuthylazine and its major Intermediate metabolites were highly mobile and present considerable leachability in soil (European Food Safety Authority 2011, Viegas et al. 2019, Lewis et al. 2016). Terbutylazine was also considered to be an endocrine disruptor and carcinogen (Velisek et al. 2016). It has many negative effects on crop photosynthesis, environmental microbes and public health (Andrea et al. 2018, Tang et al. 2019, Elsheekh et al. 1994). Therefore, the rapid elimination of terbuthylazine pollution was considered to be essential to the safety of the environment.

The use of terbutylazine-degrading strains was an ideal way for the remediation of terbutylazine pollution because it was cost-effective and environmentally friendly (Vaishampayan et al. 2007, Zhu et al. 2019b, Li et al. 2020). Recently, a bioremediation tool consisting of live cells of $A$. aurescens TC1 has been successfully used to repair the terbuthylazine-contaminated soil (Viegas et al. 2019, Silva et al. 2015). This method required prior acquisition of pure strains or microbial consortium with high degradation performance (Zhu et al. 2019c, Sagarkar et al. 2014, Lu et al. 2020, Kou et al. 2020). In addition, many factors such as temperature, $\mathrm{pH}$ and oxygen content usually affect the biodegradation of terbuthylazine (Mueller et al. 2010, Getenga et al. 2009, Zhao et al. 2019, Hou et al. 2019). Therefore, in addition to screening high-efficiency terbutylazinedegrading strains, attention should also be paid to the effects of various environmental factors on the biodegradation of terbutylazine (Pinto et al. 2012, Zhu et al. 2018, Ding et al. 2019, Caracciolo et al. 2010). 
In this study, two high-efficiency terbutylazine-degrading strains have been isolated from soil. They could degrade many other s-triazine herbicides in addition to theirs excellent terbutylazine degradation ability. These two strains have now been developed into a microbial agent that could be used for bioremediation of terbutylazine pollution.

\section{MATERIALS AND METHODS}

\section{Chemicals and media}

Terbutylazine (99.2\%) was purchased from Fisher Company. All other chemicals used were of analytical grade or chromatographic grade.

Inorganic salt medium: $\left(\mathrm{NH}_{4}\right)_{2} \mathrm{SO}_{4} 0.1 \mathrm{~g}$, $\mathrm{K}_{2} \mathrm{HPO}_{4} 0.1 \mathrm{~g}, \mathrm{CaSO}_{4} 0.05 \mathrm{~g}, \mathrm{MgSO}_{4} \cdot 7 \mathrm{H}_{2} \mathrm{O} 0.2 \mathrm{~g}$, $\mathrm{FeSO}_{4} \cdot 7 \mathrm{H}_{2} \mathrm{O} 0.01 \mathrm{~g}$, distilled water $1.0 \mathrm{~L}, \mathrm{pH} 7.0$.

Isolation medium: $\left(\mathrm{NH}_{4}\right)_{2} \mathrm{SO}_{4} 0.1 \mathrm{~g}, \mathrm{~K}_{2} \mathrm{HPO}_{4}$ $0.1 \mathrm{~g}, \mathrm{CaSO}_{4} 0.05 \mathrm{~g}, \mathrm{MgSO}_{4} \cdot 7 \mathrm{H}_{2} \mathrm{O} 0.2 \mathrm{~g}, \mathrm{FeSO}_{4} \cdot 7 \mathrm{H}_{2} \mathrm{O}$ $0.01 \mathrm{~g}$, yeast extract powder $1.5 \mathrm{~g}$, beef extract powder $2.0 \mathrm{~g}$, terbutylazine $10 \mathrm{mg}$, distilled water $1.0 \mathrm{~L}, \mathrm{pH}$ 7.0. (The final concentration of terbutylazine was $10 \mathrm{mg} / \mathrm{L}$.).

\section{Determination of terbutylazine}

The various samples were pretreated and extracted for the determinations of terbutylazine according to the method described in the literature (Zhu et al. 2020). The extracts were analyzed by LC-MS/MS on 1260HPLC-6430Triple quadrupole mass spectrometer (Agilent ${ }^{\mathrm{TM}}$, USA). Terbutylazine was separated on a C18 chromatographic column (Agilent ${ }^{\text {TM }}, 3.0 \times 100 \mathrm{~mm}$, 1.8-Micron) with a flow rate of $0.3 \mathrm{ml} / \mathrm{min}$. $0.1 \%$ formic acid-water solution and acetonitrile were used for gradient elution. MS/MS analysis was performed in ESI positive mode and transitions were measured in MRM. The parameters of terbutylazine for MS/MS analysis: (precursor ion: 230, product ion: 174/132, fragmenter: 124 , CE: 15/25).

\section{Isolation of terbutylazine degrading strains}

Soil samples were taken from the forest land of Nantong, China, where terbutylazine has been used for about ten years. Add $6.0 \mathrm{~g}$ of soil sample to $100 \mathrm{ml}$ of isolation medium, mix well, and then shake culture at $30^{\circ} \mathrm{C}$. The content of terbutylazine in medium was determined every 24 hours, the assay method refer to previous studies (Cabras et al. 1989, Bichon et al. 2006, Mercadante et al. 2012). Transfer $5 \mathrm{ml}$ of culture solution with 3-day degradation efficiency $>70 \%$ to an enriched medium containing $10 \mathrm{mg} / \mathrm{L}$ terbutylazine, and continuously subculture for more than 5 times. After the degradation ability was retested to ensure that the 3-day degradation efficiency was more than $70 \%$, the above-mentioned enriched culture solution was inoculated in an inorganic salt culture plate containing terbutylazine, and inverted culture was carried out $\left(30^{\circ} \mathrm{C}\right)$. Select the colony with vigorous growth, and draw lines repeatedly on the culture plate to obtain a pure culture. The strains were identified by 16 SrRNA analysis, and build a phylogenetic tree (Wang et al. 2012, Min et al. 2019, Fan et al. 2020).

\section{Bacterial inocula}

Terbutylazine-degrading strains, Bacillus pumilus TDJ-7 and Bacillus subtilis TDJ-9 have been isolated from soil. The strains were inoculated into an enriched medium containing $10 \mathrm{mg} / \mathrm{L}$ terbutylazine for shake culture at $30^{\circ} \mathrm{C}$ (100 rpm). After 24 hours of culture, collect bacterial cells by centrifugation and rinse with sterile water (Zhu et al. 2019a, Xu et al. 2020, Luo et al. 2021). The bacterial cells were resuspended in normal saline as inoculum of the subsequent experiments, and the concentration was approximately $2 \times 10^{6}$ cells $/ \mathrm{ml}$.

\section{Degradation of terbutylazine by strain TDJ-7 and TDJ-9}

Inoculate 5\% strain TDJ-7 inoculum into the isolation medium containing $10 \mathrm{mg} / \mathrm{L}$ 
terbutylazine, and incubate at $30^{\circ} \mathrm{C}(100 \mathrm{rpm})$ The amount of terbutylazine residue was measured every 24 hours. In addition, the strain TDJ-9 was studied synchronously according to the same experimental process.

2.5\% strain TDJ-7 inoculum and 2.5\% TDJ9 inoculum were simultaneously added into the isolation medium containing $10 \mathrm{mg} / \mathrm{L}$ terbutylazine, incubate at $30^{\circ} \mathrm{C}(100 \mathrm{rpm})$. The amount of terbutylazine residue was determined periodically.

\section{Tolerance of strain TDJ-7 and TDJ-9 on terbutylazine}

The content of terbutylazine in isolation medium was adjusted respectively to 5, 10, 20, 50 and $100 \mathrm{mg} / \mathrm{L}$ by applying terbutylazine wettable powder. Then, strain TDJ-7 was inoculated for shake culture, and $\mathrm{OD}_{600}$ was determined periodically for evaluating the tolerance of strains on terbutylazine. The strain TDJ-9 was studied synchronously according to the same experimental process.

\section{Degradation of atrazine, metribuzin, simazine and ametryn by strain TDJ-7 and strain TDJ-9}

Four kinds of media containing different herbicides were prepared by replacing terbutylazine in the isolation medium with atrazine, metribuzin, simazine and ametryn respectively, the final concentration of herbicide was $20 \mathrm{mg} / \mathrm{L}$.

$5 \%$ strain TDJ-7 inoculum was inoculated in the above prepared medium containing $20 \mathrm{mg} / \mathrm{L}$ atrazine for shake culture at $30^{\circ} \mathrm{C}(100 \mathrm{rpm})$. The amount of atrazine residue was determined periodically. Testing for other 3 s-triazine herbicides were carried out simultaneously in the same manner.

The degradation of $4 \mathrm{~s}$-triazine herbicides by strain TDJ-9 was tested synchronously as described above.

\section{Development of the microbial agent for bioremediation of terbutylazine pollution}

2.5\% strain TDJ-7 inoculum and 2.5\% TDJ-9 inoculum were simultaneously inoculated into enrichment medium, incubated for 6 hours at $30^{\circ} \mathrm{C}$ (100rpm). Finally, this microbial consortium was stored at $-4^{\circ} \mathrm{C}$ for subsequent studies.

Isolation medium containing $10 \mathrm{mg} / \mathrm{L}$ terbutylazine was divided into 3 groups. I. In the first group, $3 \%(\mathrm{v} / \mathrm{v})$ of the above microbial consortium were added, and Populus alba rhizosphere soil was also added (add 2 g soil per $100 \mathrm{ml}$ medium). II. Add only $3 \%$ microbial consortium. III. Control group. Finally, the above 3 groups were cultured at $30^{\circ} \mathrm{C}$, and the content of terbutylazine was determined periodically.

Preparation for microbial agent containing strain TDJ-7 and TDJ-9 (Zhu et al. 2019a): TDJ-7 inoculum, TDJ-9 inoculum and sterile nutrient broth were mixed (1:1:2, $v / v)$, the mixed solution was cultured at $30^{\circ} \mathrm{C}$ for 12 hours. Mixture of fresh Populus alba rhizosphere soil and rice bran flour (1:9, w/w) was used as carrier, and each $0.4 \mathrm{~kg}$ carrier was mixed with $100 \mathrm{ml}$ pre-made mixed solution. The mixture was incubated at $30^{\circ} \mathrm{C}$ for 12 hours, and agitated every 4 hours. Finally, store them in a sterile jar at $-4^{\circ} \mathrm{C}$.

Degradation of terbutylazine by new microbial agent: Add terbutylazine to fresh soil (the parameters of soil were shown in Table I) to a concentration of $10 \mathrm{mg} / \mathrm{kg}$, and put the soil in $0.3 \mathrm{~m} \times 0.3 \mathrm{~m}$ plastic boxes making $0.1 \mathrm{~m}$ depth, to ensure that the weight of each box of soil was the same. Follow the steps below to add the microbial agent to the soil: Mix 1.5 $\mathrm{g}$ of the microbial agent with $100 \mathrm{ml}$ of sterile water and sprinkle it all on a box of soil. Only $100 \mathrm{ml}$ of sterile water was sprinkled into the control group. Then all of them were incubated at $30^{\circ} \mathrm{C}$ for more than 7 days and turned every 6 hours. The content of terbutylazine in soil was determined periodically. 
Table I. Basic physic-chemical characteristics of fresh soil.

\begin{tabular}{|c|c|c|c|c|c|c|}
\hline Soil type & $\mathrm{pH}$ & $\begin{array}{c}\text { Total phosphorus } \\
\text { g.kg-1 }\end{array}$ & $\begin{array}{c}\text { Total nitrogen } \\
\mathrm{g} \cdot \mathrm{kg}^{-1}\end{array}$ & $\begin{array}{c}\text { Organic matter } \\
\mathrm{g} \cdot \mathrm{kg}^{-1}\end{array}$ & $\begin{array}{c}\text { Total salinity } \\
\%\end{array}$ & $\begin{array}{c}\text { Water content } \\
\%\end{array}$ \\
\hline Loam & 7.1 & 0.60 & 0.55 & 27.8 & 0.19 & 26.5 \\
\hline
\end{tabular}

\section{RESULTS AND DISCUSSION}

\section{Characterization of terbutylazine-degrading strains}

2 strains that could effectively degrade terbutylazine were isolated from soil, and named TDJ-7 and TDJ-9. TDJ-7 was straight or curvulate rod-shape bacterium, 0.5-0.7×2.0$2.5 \mu \mathrm{m}$, facultative anaerobe, motile, sporeforming, Gram-positive and formed opaque rough colonies on the broth agar plate. It was positive in tests for catalase, starch hydrolysis, methyl red and V.P. test, but negative for gelatin liquefaction, indole test and oxidase, the biochemical experiments refer to previous studies (Zhu et al. 2019d, 2021, Song et al. 2020, jin et al. 2020). According to $16 \mathrm{~S}$ rRNA sequence, TDJ-7 was identified as Bacillus pumilus (GenBank accession No. MK968037).

TDJ-9 was straight rod-shape bacterium, 0.60.8×2.5-3.0 $\mu \mathrm{m}$, aerobiotic, mobile, Gram-positive, and it formed grayish-white rough colonies on the broth agar plate. It was positive for catalase, starch hydrolysis, gelatin liquefaction, oxidase and V.P. test, but negative for methyl red and indole test. TDJ-9 was identified as Bacillus subtilis (GenBank accession No. MK967996, phylogenetic trees of TDJ-7 and TDJ-9 was shown in Fig. 1).

\section{Degradation of terbutylazine by strain TDJ-7 and TDJ-9}

The results in Fig. 2 indicated that both strain TDJ-7 and strain TDJ-9 could rapidly degrade terbutylazine. The 6-days degradation efficiency of terbutylazine (10mg/L) by TDJ-7 was approximately 95\%, while the strain TDJ-9 could reach $98 \%$ in 6 days. It could also be seen from Fig. 2 that the strain TDJ-9 degraded terbutylazine faster than TDJ-7. In addition, the experimental results showed that the combined application of TDJ-7 and TDJ-9 has achieved higher degradation rate, and the degradation efficiency of terbutylazine $(10 \mathrm{mg} / \mathrm{L})$ could reach $99 \%$ in 6 days. Therefore, the combined application of two terbutylazine-degrading bacteria was considered to be a more effective way for degrading terbutylazine.

\section{Tolerance of strain TDJ-7 and TDJ-9 on terbutylazine}

In Fig. 3, when the concentration of terbutylazine was increased from $20 \mathrm{mg} / \mathrm{L}$ to $100 \mathrm{mg} / \mathrm{L}, \mathrm{OD}_{600}$ of strain TDJ-7 did not change significantly $(P>0.05)$. If the concentration of terbutylazine was as low as $10 \mathrm{mg} / \mathrm{L}$ or $5 \mathrm{mg} / \mathrm{L}, \mathrm{OD}_{600}$ would decrease. It might be due to the activation effect of terbutylazine on the growth of the strain TDJ7, but the lower concentration of terbutylazine could not produce enough activation effect. In Fig. 4, there was no significant change in $\mathrm{OD}_{600}$ of TDJ-9 when the concentration of terbutylazine was increased from $10 \mathrm{mg} / \mathrm{L}$ to $100 \mathrm{mg} / \mathrm{L}$. Therefore, it was speculated that strain TDJ-7 and TDJ-9 were able to tolerate at least $100 \mathrm{mg} / \mathrm{L}$ of terbutylazine. Based on existing research results, it was considered that both strains had excellent degradation ability to terbutylazine, and could be used for the biodegradation of terbutylazine in a wide concentration range. 


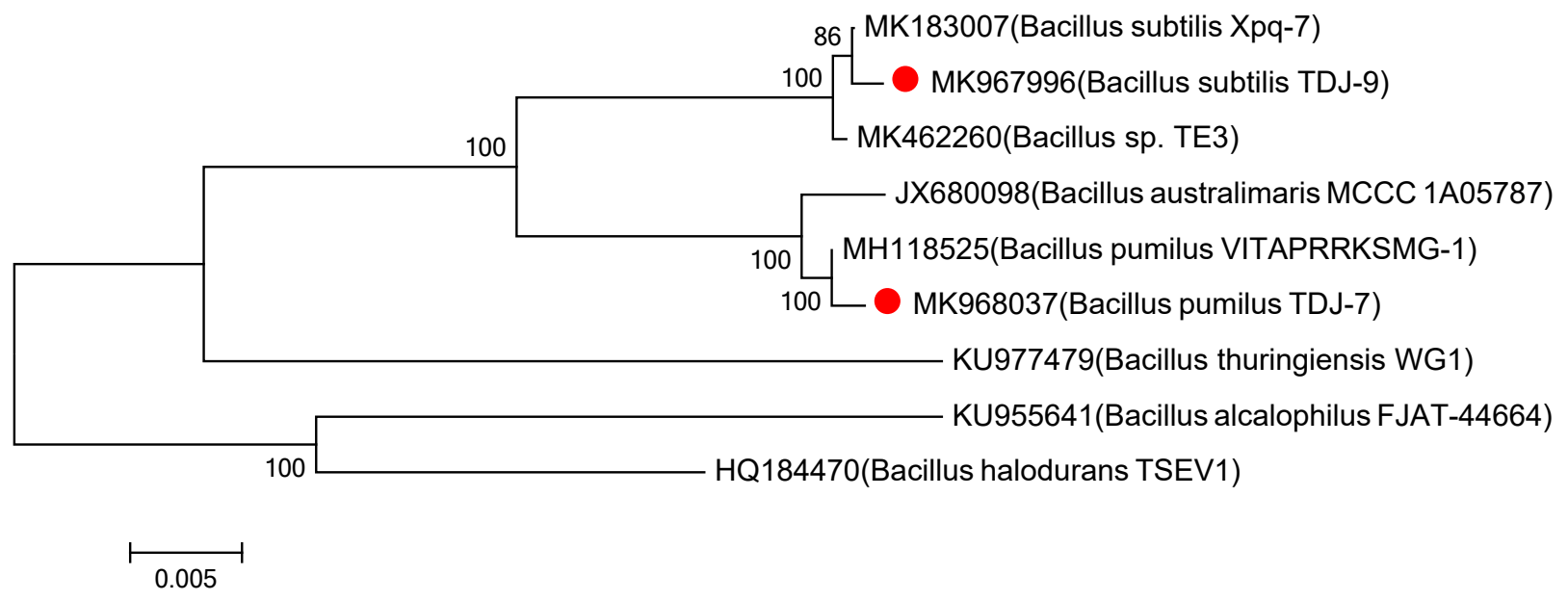

Figure 1. Phylogenetic tree of TDJ-7 and TDJ-9.
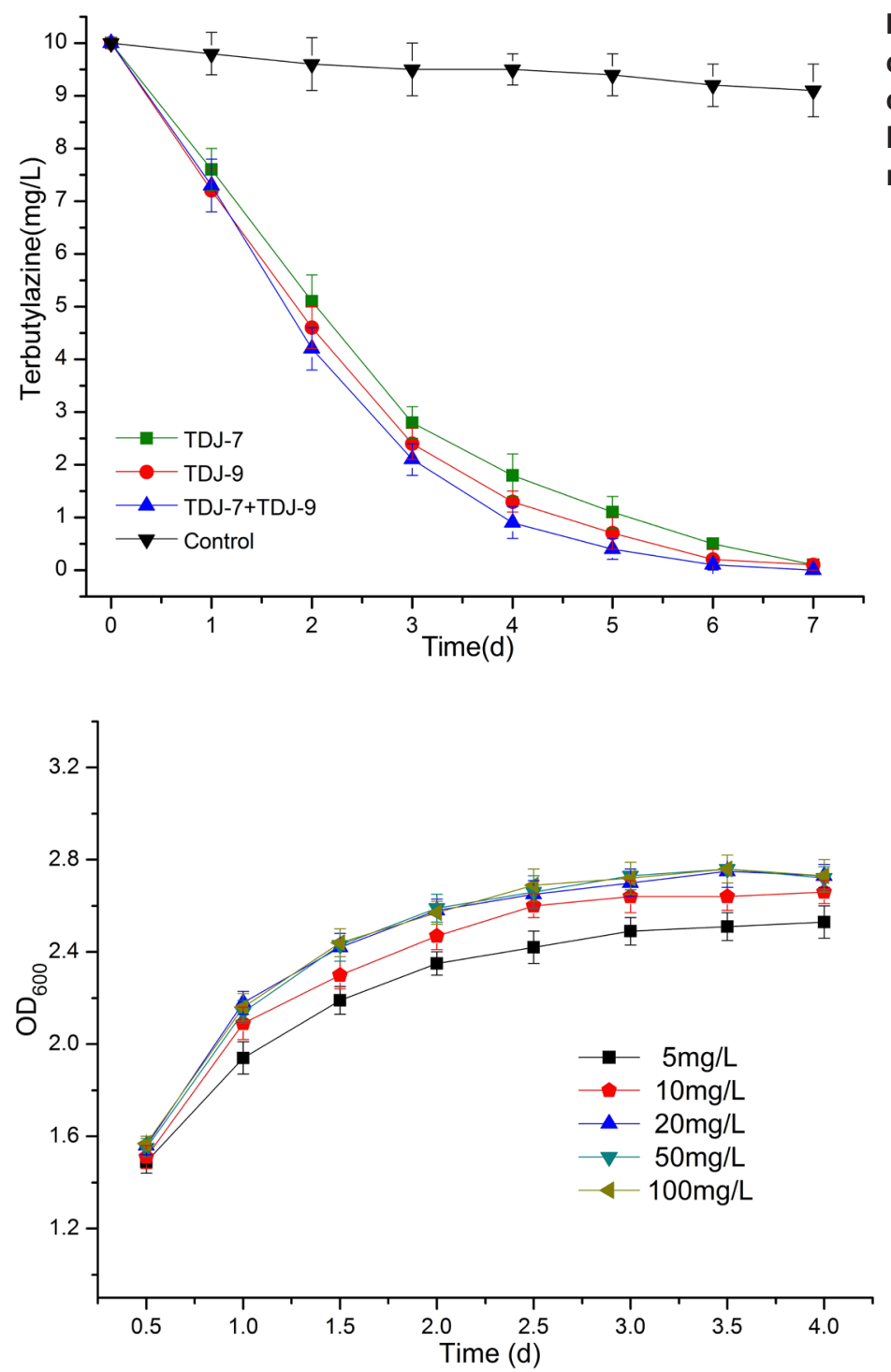

Figure 2. The curve on degradation of terbutylazine by different microorganisms.
Figure 3. Effect of concentration of terbutylazine on the growth of TDJ-7. 


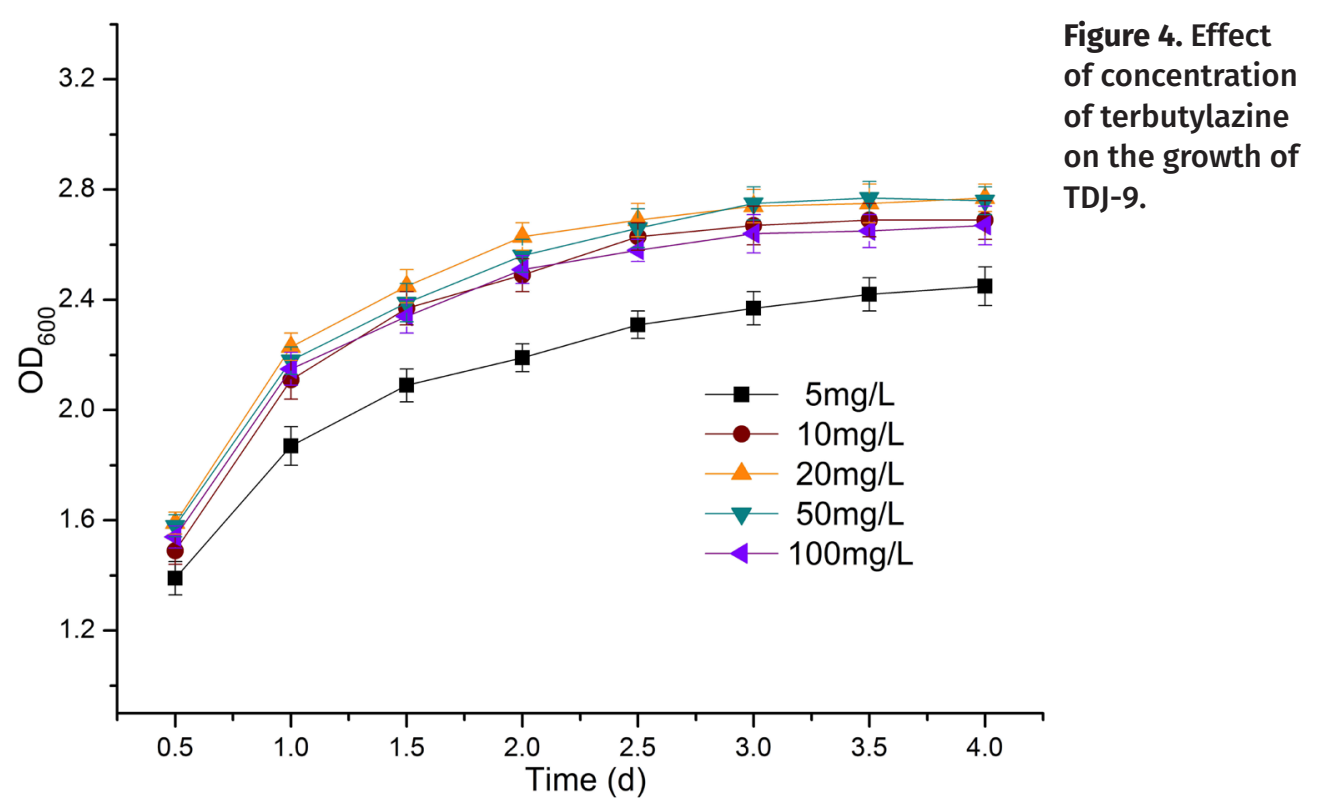

\section{Degradation of atrazine, metribuzin, simazine and ametryn by strain TDJ-7 and TDJ-9}

According to the experimental results in Fig. 5 and Fig. 6, both strain TDJ-7 and strain TDJ-9 could effectively degrade simazine, metribuzin, atrazine and ametryn. The degradation efficiencies of $4 \mathrm{~s}$-triazine herbicides by strain TDJ-7 were respectively $97.0 \%, 92.5 \%, 99.5 \%$ and $100 \%$ in $7 d$. The efficiency of strain TDJ-9 in degrading four s-triazine herbicides was higher than that of strain TDJ-7, and the 7-day degradation efficiencies were $98.5 \%, 96.0 \%, 100 \%$ and $100 \%$, respectively. In addition, the above experimental results have also shown that the strain TDJ-9 degrade terbutylazine faster than the strain TDJ-7. Usually the s-triazine herbicides contained a common s-triazine structure. Some microorganisms or enzymes capable of cleaving s-triazine structure may have the ability to degrade a variety of s-triazine herbicides. It was speculated that both strains TDJ-7 and TDJ9 may have the ability to cleave the s-triazine structure. Therefore, these two strains were also supposed to be used for bioremediation of some other s-triazine herbicides contamination, not just degradation of terbutylazine.

\section{Degradation of terbutylazine by the microbial agent}

The degradation efficiency of terbutylazine $(10 \mathrm{mg} / \mathrm{L}$ ) by the microbial consortium consisting of TDJ-7 and TDJ-9 could reach about $96.0 \%$ in $5 d$ (Fig. 7). If the microbial consortium and Populus alba rhizosphere soil were jointly applied to degrade terbutylazine, its degradation rate could be significantly improved, and the 5-day degradation efficiency could reach $99.0 \%$. It was speculated that these should be caused by some special microorganisms, enzymes or trace organic compounds in Populus alba rhizosphere soil. Therefore, adding appropriate amount of Populus alba rhizosphere soil may be an effective way to improve the degradation effect in the preparation of microbial agents.

The degradation efficiency of $10 \mathrm{mg} / \mathrm{kg}$ of terbutylazine in soil could reach $96.0 \%$ by new microbial agent after 7 days of incubation (Fig. 7). In the control group (no microbial agent), the degradation efficiency of terbutylazine was $11.0 \%$ in $7 d$, which should be attributed to 


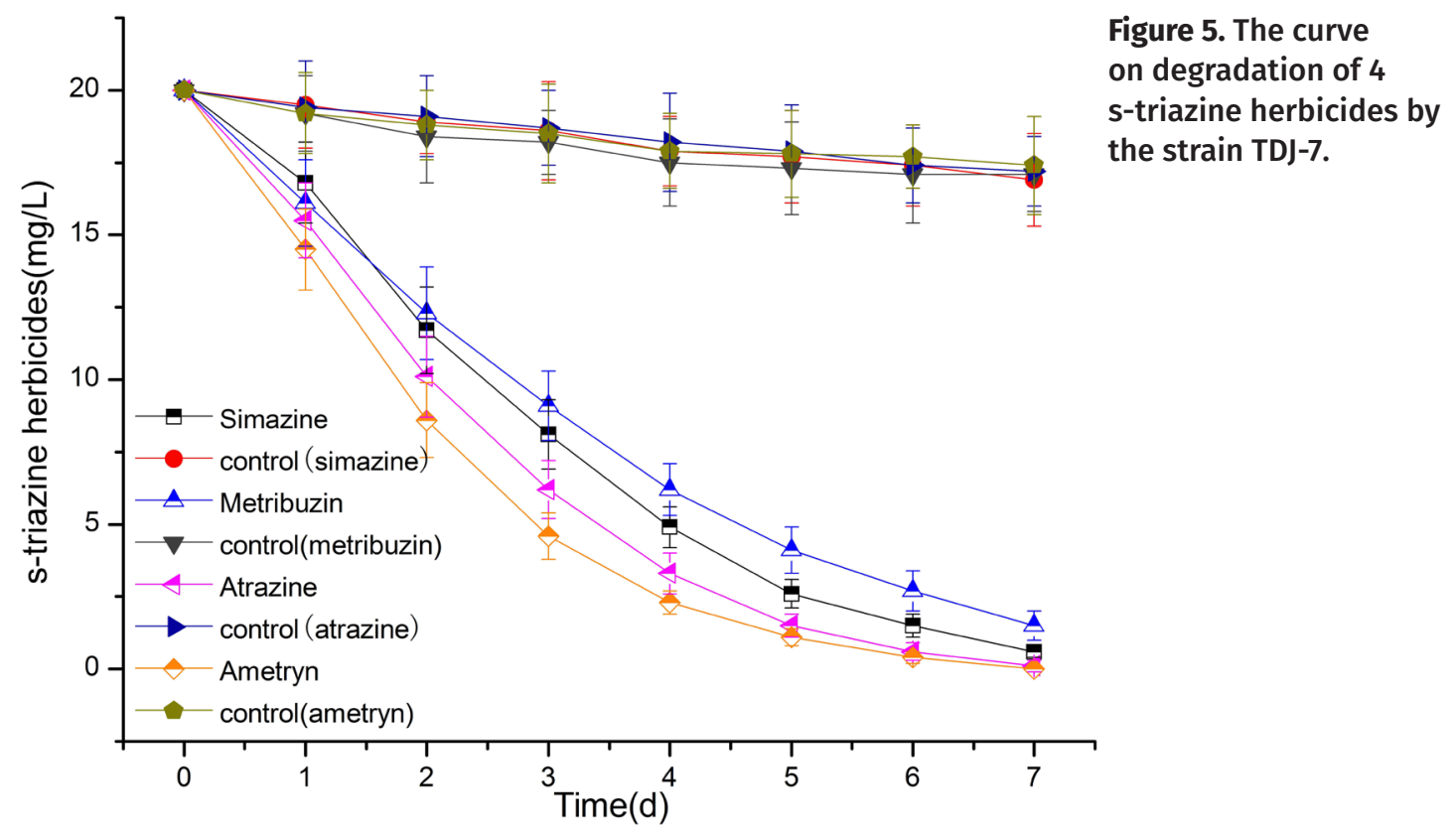

some natural microorganisms, soil enzymes and other physical or chemical factors. These results indicated that the development of new microbial agents has been successful and that their products could be used for bioremediation of terbutylazine contamination.

\section{CONCLUSION}

Two terbutylazine degrading strains were isolated from soil, and they were Bacillus pumilus TDJ-7 and Bacillus subtilis TDJ-9. The degradation efficiency of $10 \mathrm{mg} / \mathrm{L}$ of terbutylazine by TDJ-7 could reach about $95 \%$ in $6 \mathrm{~d}$, and the strain TDJ-9 could reach $98 \%$ under the same conditions. The combination of the two strains could significantly accelerate the degradation of terbutylazine. Adding an appropriate amount of Populus alba rhizosphere soil during the microbial degradation of terbutylazine could also improve the degradation rate. In addition, both TDJ-7 and TDJ-9 could effectively degrade simazine, metribuzin, atrazine and ametryn. TDJ7 and TDJ-9 have been successfully developed into a microbial agent. The new microbial agent could be used to degrade terbutylazine in soil, and have achieved many satisfactory results. According to the results of this study, we believed that it was an attractive choice to use the isolated terbutylazine-degrading bacteria to clean up contaminated sites. TDJ-7, TDJ-9 and their microbial agent could be used for the bioremediation of terbutylazine or other s-triazine herbicides contamination.

\section{Acknowledgments}

This study was funded by the National Key Research and Development Plan of China (No. 2016YFD0600204) and China Postdoctoral Science Foundation (No.2017M611827), and partially by the Priority Academic Program Development of Jiangsu Higher Education Institutions. The authors declare that they have no known competing financial interests or personal relationships that could have appeared to influence the work reported in this paper. 


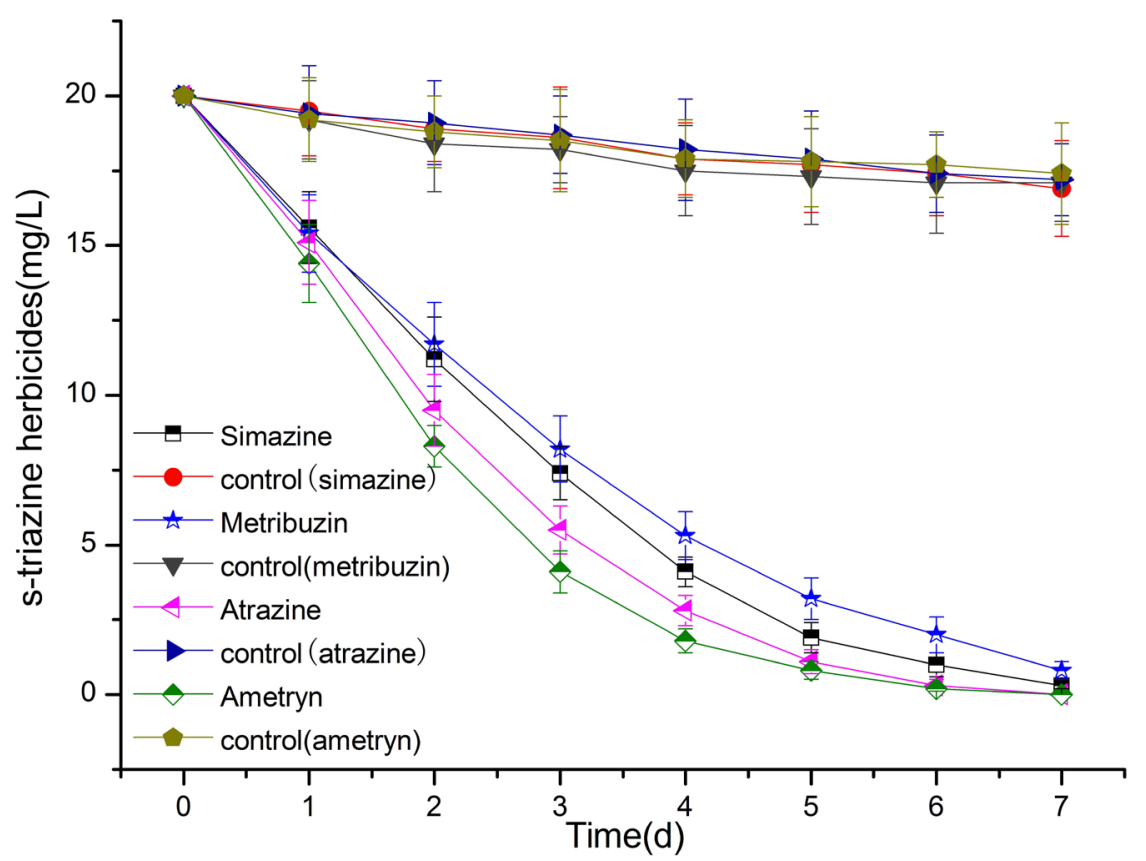

Figure 6. The curve on degradation of $4 \mathrm{~s}$-triazine herbicides by the strain TDJ-9.
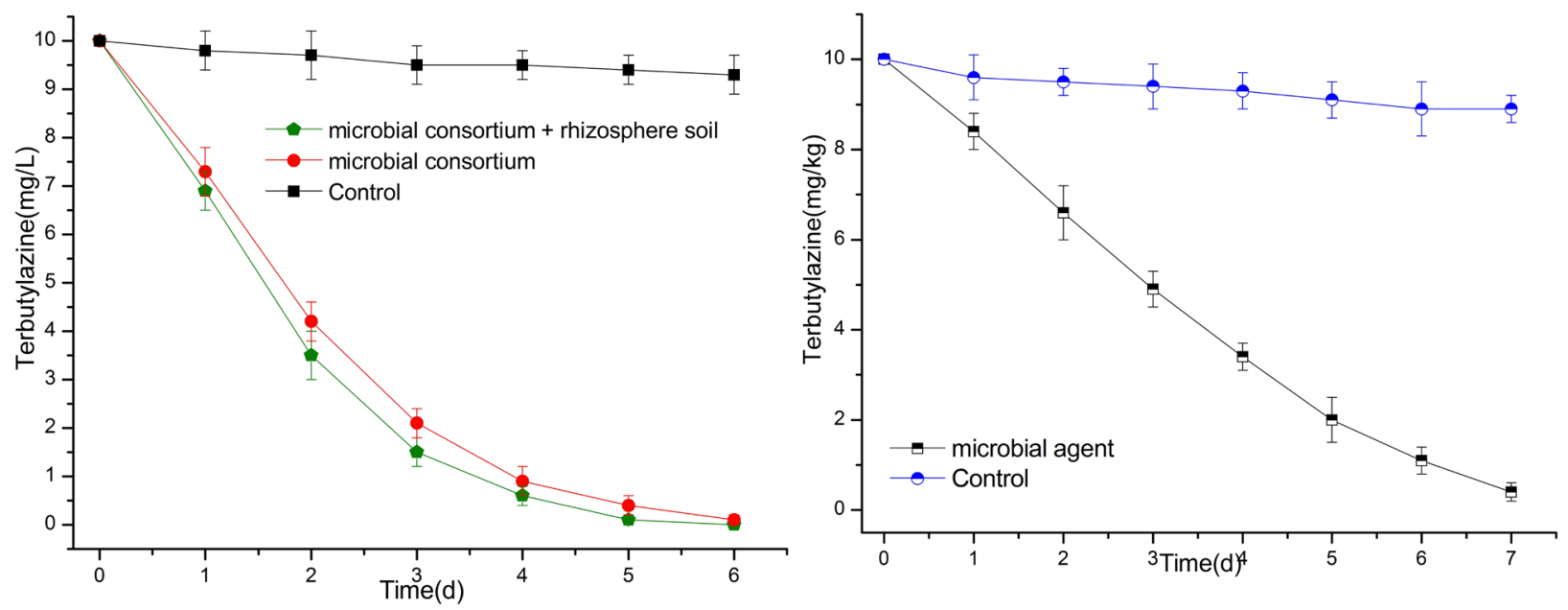

Figure 7. (1)Degradation of terbutylazine by microbial consortium and rhizosphere soil. (2)Degradation of terbutylazine in soil by microbial agent.

\section{REFERENCES}

ANDREA LT, MONICA P \& ASHLEIGH F. 2018. Terbuthylazine and desethylterbuthylazine: Recent occurrence, mobility and removal techniques. Chemosphere 202: 94-104.

BICHON E, DUPUIS M, BIZEC BL \& ANDRÉ F. 2006. LC-ESI-MS/ MS determination of phenylurea and triazine herbicides and their dealkylated degradation products in oysters. Chromatogr B 838(2): 96-106.

BOTTONI P, GRENNI P, LUCENTINI L \& CARACCIOLO AB. 2013. Terbuthylazine and other triazines in Italian water resources. Microchem J 107: 136-142.
BROWN JH. 2018. Electrochemical reduction of terbuthylazine under acidic conditions and structural determination of post-electrolysis product with the aid of GC/MS, IR, and, 1H NMR spectroscopy. J Electroanal Chem 809: 125-129.

CABRAS P, SPANEDDA L, PELLECCHIA M \& GENNARI M. 1989. Highperformance liquid chromatographic determination of the herbicide terbutylazine and its dealkylated metabolites in soil. J Chromatogr A 472(2): 411-415.

CARACCIOLO AB, FAJARDO C, GRENNI P \& CICCOLI R. 2010. The role of a groundwater bacterial community in the 
degradation of the herbicide terbuthylazine. FEMS Microbiol Ecol 71(1): 127-136.

DING S, WANG Y, LU L, ZHANG Y, JIANG M, WEI Q \& YE J. 2019. Isolation-screening and identification of an endophytic bacteria in Ceresas with resistance to Agrobacterium tumefaciens and phosphorus solubilizing ability. J Nanjing Forest Univ 43(5): 81-88.

EFSA - EUROPEAN FOOD SAFETY AUTHORITY. 2011. Conclusion on the peer review of the pesticide risk assessment of the active substance terbuthylazine. EFSA J 9(1): 1969.

ELSHEEKH MM, KOTKAT HM \& HAMMOUDA OH. 1994. Effect of atrazine herbicide on growth, photosynthesis, protein synthesis, and fatty acid composition in the unicellular green alga Chlorella kessleri. Ecotox Environ Safe 29: 349-358.

FAN R, HE X, YE W, CAI Z \& HU S. 2020. Isolation, identification and growth inhibition of microorganisms mildew of fiberboard. J Forest Eng 5(5): 84-89.

GETENGA Z, DÖRFLER U, IWOBI A, SCHMID M \& SCHROLL R. 2009. Atrazine and terbuthylazine mineralization by an Arthrobacter sp. isolated from a sugarcane-cultivated soil in Kenya. Chemosphere 77: 534-539.

HOU X, XIAO H \& PAN Y. 2019. Research progress of stimuliresponsive nanomaterials on controlled-release of agrochemicals. J Forest Eng 4(2): 19-25.

JIN Y, CHEN H, WU W \& WEI W. 2020. Investigations of the effect of water-soluble lignin on enzymatic hydrolysis of lignocellulose. J Forest Eng 5(4): 12-19.

KOU X, XIE N, WU C, FAN G \& FU X. 2020. Isolation and identification of endophytic fungi from Cyclocarya paliurus (Batal.) Iljinskaja. J Nanjing Forest Univ 44(2): 26-34.

LEWIS KA, TZILIVAKIS J, WARNER DJ \& GREEN A. 2016. An international database for pesticide risk assessments and management. Hum Ecol Risk Assess 22(4): 1050-1064.

LI W, LI J, LYU B \& ZHANG Y. 2020. Pollution characteristics of antibiotics in different environment media in China: a review. J Nanjing Forest Univ 44(1): 205-214.

LU W, GENG H, ZHANG Y \& RUAN H. 2020. Effects of biochars pyrolyzed at different temperatures on soil microbial community in a poplar plantation in coastal eastern China. J Nanjing Forest Univ 44(4): 143-150.

LUO J, DONG Y \& ZHANG S. 2021. Soluble expression and applications of thermostable $\beta$-xylosidase. J Forest Eng 6(3): 81-87.

MERCADANTER, POLLEDRI E \& FUSTINONIS. 2012. Determination of terbuthylazine and desethylterbuthylazine in human urine and hair samples by eletrospray ionization-liquid chromatography/triple quadrupole mass spectrometry. Anal Bioanal Chem 404(3): 875-886.

MIN L, GUO L \& YE J. 2019. Mechanism of Burkholderia pyrrocinia JK-SH007 growth-promoting to plant via sidero-phore-mediation. J Nanjing Forest Univ 43(6): $165-172$

MUELLER TC, STECKEL LE \& RADOSEVICH M. 2010. Effect of soil ph and previous atrazine use history on atrazine degradation in a tennessee field soil. Weed Sci 58(4): 478-483.

PINTO AP, SERRANO C, PIRES T, MESTRINHO E, DIAS L \& TEIXEIRA DM. 2012. Degradation of terbuthylazine, difenoconazole and pendimethalin pesticides by selected fungi cultures. Sci Total Environ 435-436: 402-410.

SAGARKAR S, NOUSIAINEN A, SHALIGRAM S, BJÖRKLÖF K, LINDSTRÖM K \& KAPLEY A. 2014. Soil mesocosm studies on atrazine bioremediation. J Environ Manage 139: 208-216.

SILVA VP, MOREIRA-SANTOS M, MATEUS C, TEIXEIRA T, RIBEIRO R \& VIEGAS CA. 2015. Evaluation of Arthrobacter aurescens Strain TC1 as bioaugmentation bacterium in soils contaminated with the herbicidal substance terbuthylazine. PLoS ONE 10(12): e0144978.

SONG J, XU G, ZHAO X, YAO Y, YANG X, TANG R, CUI J, CHEN F \& REN J. 2020. Screening of indigenous phosphate-solubilizing bacteria from Liquidambar formosana Hance rhizosphere and its potential applications for improving plant growth. J Nanjing Forest Univ 44(3): 95-104.

TANG J, CHEN Y \& DONG Z. 2019. Effect of crystalline structure on terbuthylazine degradation by $\mathrm{H}_{2} \mathrm{O}_{2}$-assisted $\mathrm{TiO}_{2}$ photocatalysis under visible irradiation. J Environ Sci 79: 153-160.

VAISHAMPAYAN PA, KANEKAR PP \& DHAKEPHALKAR PK. 2007. Isolation and characterization of Arthrobacter, sp. strain MCM B-436, an atrazine-degrading bacterium, from rhizospheric soil. Int Biodeter Biodegr 60(4): 273-278.

VELISEK J, KOUTNIK D, ZUSKOVA E \& STARA A. 2016. Effects of the terbuthylazine metabolite terbuthylazine-desethyl on common carp embryos and larvae. Sci Total Environ 539: $214-220$

VIEGAS CA, SILVA VP, VARELA VM, CORREIA V \& RIBEIRO R. 2019. Evaluating formulation and storage of Arthrobacter aurescens strain TC1 as a bioremediation tool for terbuthylazine contaminated soils: Efficacy on abatement of aquatic ecotoxicity. Sci Total Environ 668: 714-722.

WANG S, ZHANG C \& YAN Y. 2012. Biodegradation of methyl parathion and $\mathrm{p}$-nitrophenol by a newly isolated 
Agrobacterium sp. strain Yw12. Biodegradation 23(1): 107-116.

XU R, ZHANG X, PAN Y, ZHANG Y, LI X \& WANG F. 2020. Expression, purification and characterization of lipase from Thermosyntropha lipolytica. J Forest Eng 5(3): 108-114.

ZHAO Y, ZHAO C, TONG S \& JIN C. 2019. Study on isolation and utilization of a chlorothalonil degrading bacterium, Bacillus coagulans BJQ-Z6. Fresen Environ Bull 28(4): 2426-2432.

ZHU J, FU L \& JIN C. 2019a. Study on the biodegradation characteristics of isofenphos-methyl and isolation of an isofenphos-methyl degrading bacterium, Bacillus atrophaeus IM-5. Fresen Environ Bull 28(3): 1794-1800.

ZHU J, FU L, JIN C, MENG Z \& YANG N. 2019b. Study on the isolation of two atrazine-degrading bacteria and the development of a microbial agent. Microorganisms 7: 80.

ZHU J, FU L, MENG Z \& JIN C. 2021. Characteristics of an atrazine degrading bacterium and the construction of a microbial agent for effective atrazine degradation. Water Environ J 35: 7-17.

ZHU J, ZHAO Y, FU L, LIU Z, LI X \& MENG Z. 2020. Application of a simazine degrading bacterium, Arthrobacter ureafaciens XMJ-Z01 for bioremediation of simazine pollution. Water Environ J 34: 561-572.

ZHU J, ZHAO Y, LIX \& CHEN W. 2018. Effects of chlorimuronethyl on soil microorganisms and enzyme activities under moderate salt stress. Fresen Environ Bull 27(4): 2358-2365.

ZHU J, ZHAO Y \& RUAN H. 2019c. Comparative study on the biodegradation of chlorpyrifos methyl by Bacillus megaterium CM-Z19 and Pseudomonas syringae CM-Z6. An Acad Bras Cienc 91: e20180694.

ZHU L, WU S, OUYANG S, TANG S \& LI X. 2019d. Effect of addition of amino acids on production of hyaluronic acid by Streptococcus zooepidemicus. J Forest Eng 4(3): 74-79.

\section{How to cite}

ZHU J, ZHAO Y, LI X \& FU L. 2022. Characteristics of two terbutylazinedegrading bacteria and the construction of a live bacterial agent for effective degradation of terbutylazine in soil. An Acad Bras Cienc 94: e2020065. DOI 10.1590/0001-3765202220200658.
Manuscript received on April 30, 2020;

accepted for publication on December 18, 2020

\section{JIANGWEI ZHU}

https://orcid.org/0000-0003-0913-3435

\section{YAN ZHAO ${ }^{2}$}

https://orcid.org/0000-0001-9080-5256

\section{XIAOLOU LI}

https://orcid.org/0000-0002-9401-6753

\section{FU}

https://orcid.org/0000-0002-5957-7790

${ }^{1}$ Co-Innovation Center for Sustainable Forestry in Southern China, Nanjing Forestry University, Nanjing 210037, China

${ }^{2}$ National Institute of Quality Inspection and Research on Product in Shanghai, Shanghai 201114, China

${ }^{3}$ Architecture and Environmental Engineering Department, Sichuan Vocational and Technological College, Suining 629000, China

${ }^{4}$ College of Materials and Environmental Engineering, Hangzhou Dianzi University, Hangzhou 310018, China

Correspondence to: Jiangwei Zhu

E-mail:jw_zhu2016@qq.com

\section{Author contributions}

All authors contributed to the study conception and design. Material preparation, data collection and analysis were performed by Jiangwei Zhu and Yan Zhao. Xiaolou Li and Li Fu supervised both the experimental design and data acquisition. The first draft of the manuscript was written by Jiangwei Zhu, and all authors commented and corrected the manuscript. All authors have read and approved the final manuscript.

\section{(cc) BY}

